\title{
TRANS-CULTURAL NURSING: EXPLORING THE EXPERIENCES OF INTERNATIONAL STUDENTS VISITING NAMIBIA
}

\section{Ms L Pretorius}

RN M.N.Sc

Lecturer, Nursing, Faculty of Medical and Health Sciences, University of Namibia

\section{Prof L Small}

RN D.N.Sc

Associate Professor, Nursing, Faculty of Medical and Health Sciences, University of Namibia

Corresponding author: Ismall@unam.na

Keywords: trans-cultural nursing; cultural encounter; culture shock

\begin{abstract}
In a rapidly changing world, where people from diverse cultures move about more readily, nurses may find themselves faced with patients and clients with a totally different world perspective and health belief system. Because this aspect has long been recognised by nurse educators, many educational institutions, in a proactive fashion, have incorporated trans-cultural nursing content in their nursing curricula. As possible options for students to gain clinical exposure in caring for a culturally diverse population, educational visits by student nurses to foreign countries have been increasingly accepted and credited. Namibia is amongst the countries that are visited by foreign nursing students, who are usually well-prepared with regard to what is required during their clinical exposure, as their educational institutions provide them with instructions and objectives. However, they are not as well-prepared in respect of "acclimatising" to the country per se and the world view of Namibians. In fact, it appears that there is a huge gap between their expectations and reality. Consequently, it becomes necessary to provide them with basic guidelines to bridge this discrepancy and to make their visit more meaningful. A qualitative, explorative, descriptive and contextual study was conducted to determine the nature of their experiences. Data were collected over a period of four years by means of narratives that were written by students who had spent at least 12 weeks within the Namibian health care services as visiting nurses. Three themes emerged, namely (1) experiences relating to recognition of differences in care delivery, (2) experiences relating to feelings of culture shock, and (3) appreciation for experiencing a cultural encounter. Based on these themes, guidelines were constructed. These guidelines addressed aspects such as the health structure of the country, health belief systems, legal aspects, and the philosophy of nursing care in Namibia.
\end{abstract}

\section{ABSTRAK}

In 'n wêreld wat vinnig verander vind ons dat persone van uiteenlopende kulture meer migreer. Verpleegkundiges bevind hulle midde in die proses en kom gevolglik in kontak met pasiënte en kliënte met 'n ander wêreld-en gesondheidsbeskouing. Verpleegopvoeders is alreeds vir ' $n$ lang tyderk bewus van die tendens wat blyk uit die proaktiewe insluiting van transkulturele inhoud in verpleegkurrikula. Namibië is een van die lande wat besoek word deur verpleegstudente. Vanuit 'n akademiese oogpunt is die studente heel goed voorberei aangesien hulle die nodige instruksies en doelwitte van hulle opleidingsinstansies ontvang het. Die meeste besoekende studente het in die verlede kommentaar gelewer op die "akklimatisering" van die land en die wêreldbeskouing van die Namibiërs. Dit blyk dat hulle totaal verskillende verwagtinge gehad het as wat hulle ervaar het. Dit het dus nodig geword dat hulle die nodige basiese riglyne moes ontvang om die diskrepansie te oorbrug en om hulle besoek meer betekenisvol te maak. 'n Kwalitatiewe, verkennende, beskrywende en kontekstuele studie is gedoen om die aard van hulle ervaringe te bepaal. Data is oor ' $n$ tydperk van vier jaar ingesamel en het bestaan uit die narratiewe wat geskryf is deur studente wat ten minste 12 weke in die Namibiese gesondheidsdienste deurgebring het as besoekende 
verpleegkundiges. Drie temas is uit die data verkry. Hierdie temas het inges/uit (1) gevoelens van erkenning van verskille in verpleegsorg, (2) gevoelens van kultuurskok, en (3) dankbaarheid vir die geleentheid om ' $n$ kulturele wisselwerking te beleef. Op grond van hierdie temas is riglyne ontwikkel. Die riglyne behels aspekte soos die gesondheidstruktuur van die land, gesondheidsgesindhede en oortuigings, sowel as die wetlike aspekte en die filosofie van gesondheidsorg in Namibië.

\section{INTRODUCTION}

It is necessary for nurses all over the world to learn about different cultures locally and worldwide. The third millennium is challenging nurses and other health care professionals to think and act with a global perspective since no matter where they live, nurses are providing care to increasingly diverse populations (Leininger \& McFarland, 2002:3; Polt, 2005:1).

This exposure to diverse populations is due to migration trends, as well as to the adventurous spirit of many nurses. As part of a process of spiritual enrichment and growth, and also to complement the practical component of a trans-cultural curriculum, many want to experience other cultures. In addition, the reality of a rapidly changing world, where people from diverse cultures move about more readily, confronts nurses with patients and clients with a totally different world perspective and health belief system to their own.

The preceding facts imply that nurses need to be prepared to be open and sensitive to cultures different to those in which they have trained. This has long been recognised by nurse educators, and many educational institutions, in a proactive fashion, incorporate transcultural nursing content in their nursing curricula. Transcultural nursing, as stated by Andrews and Boyle (1999:5) transcends cultural boundaries, seeking to find the essence of nursing. Its central purpose and goal is to promote and adapt to recognise the cultural needs of human beings. As possible options for students to gain clinical exposure in caring for culturally diverse populations, educational visits by student nurses to foreign countries have increasingly been accepted and credited.

Nurses, who are able to work amidst different cultures, learn how to discover and provide safe and meaningful care to people of diverse cultures (Leininger \& McFarland, 2002:4). They also consider trans-cultural nursing to be necessary to prepare a new generation of nurses with the necessary knowledge, sensitivity and competencies to care for different people.

\section{BACKGROUND AND RATIONALE}

Anthropological studies have indicated that every human being is ethnocentric, which implies that as human beings we subconsciously tend to view other people with our own customs as the standard for judgment. As professional nurses, one should be aware of one's ethnocentric tendencies and develop strategies to avoid imposing one's own cultural beliefs on others (Andrews \& Boyle, 1999:4). Trans-cultural nursing provides an ideal opportunity to become aware of cultural diversities in national and global populations.

Namibia has certainly experienced trans-cultural nursing. After Independence in 1990, European students became interested in learning more about the health care system of Namibia. After 1995 Scandinavian nurses followed. At first students were hesitant about coming to Namibia but the trend escalated recently. Through the Department of Nursing at the University of Namibia, students from all over the world have applied to visit the health services of Namibia for one clinical period during their studies (Pretorius, 1995:1). Their main aims have been to experience trans-cultural nursing care practices and to gain clinical nursing experience. Specifically, they have wanted to observe how nursing care is rendered in a multicultural country like Namibia and to be part of a trans-cultural or cross-cultural nursing programme (Pretorius, 1995:1).

It is necessary to keep in mind that cultural shock may occur with any trans-cultural encounter. In fact, cultural shock is a common phenomenon when nurses care for others from an unknown culture. Nurses may become confused, disoriented and upset when patients respond in ways that are alien to their perspectives (Leininger \& McFarland, 2002:50).

\section{PROBLEM STATEMENT}

Appropriate placements of foreign nurses can be made 
once their needs have been determined. Although these students arrive with clearly set goals and objectives from their training institutions, specific details are often omitted. Also, while accompanying these students, the coordinator at the University of Namibia has noticed that they are sometimes confused and bewildered. For instance, they have had experiences that sometimes frighten and/or surprise them. While not all of their experiences are negative - some are decidedly positive the general impression is that they have very different expectations of their visit to Namibia than the experiences they actually have. Their expectations and experiences do not seem to match.

Noticing these feelings of uncertainty and bewilderment, the coordinator (and co-researcher) anticipated that they could have been alleviated by an induction or orientation in Namibia, or better still, by providing them with information to study in preparation for their visits.

It became evident that guidelines were required; these guidelines should reflect the experiences of both the course coordinator and visiting nursing students. Of course, this required that the experiences of these visiting nursing students should be assessed and analysed. This would be a 'first' for Namibia, as no such study had been done previously.

To compile guidelines or to prepare material for these students to study beforehand, information on their experiences in Namibia was required.

\section{PURPOSE OF THE STUDY}

The focus of the study was to:

- explore and describe the experiences of student nurses visiting Namibia, relating to nursing per se; and

- develop an information guide for student nurses visiting Namibia for clinical experience.

\section{RESEARCH DESIGN}

The design for the study was qualitative, explorative, descriptive and contextual, reflecting the fact that the researchers worked inductively to explore, describe, and understand the experiences of the international nursing students (Burns \& Grove, 2005:26-27).

\section{RESEARCH METHOD}

The study was conducted in two phases, namely:

- Phase 1: Data collection and analysis.

- Phase 2: Development of information guidelines for student nurses visiting Namibia.

\section{POPULATION}

The population in this study consisted of all foreign student nurses who visited Namibia between 2001-2004 to gain clinical experience. The accessible population was 152.

\section{SAMPLING METHOD}

A purposive sampling method was used. This approach involves the conscious selection by the researcher of certain subjects or elements to be included in the study (Burns \& Grove, 2005:352).

The researcher consciously applied the following criteria to the sampling process:

- The nursing students had to be able to express themselves meaningfully in English.

- The nursing students should have been exposed to the clinical environment in Namibia for at least 12 weeks.

Thirty (30) visiting student nurses met the criteria and all of them agreed to participate in the study. Their ages ranged from 22 years to 30 years. More than 90 percent were female students. Of these 30 students, more than 50 percent were from Norway, while the remaining students were from Finland, Germany and the Netherlands.

Due to the nature of the study no pilot study was done.

\section{DATA COLLECTION METHOD}

Data were collected by asking one central question: "Describe your professional and personal experience during your visit to Namibia". The nursing students were asked to provide written responses.

\section{DATA ANALYSIS}

Data analysis was based on the method of Giorgi which 
entails reading through the entire description to get a picture of the whole. From the descriptions, patterns and themes were derived (Burns \& Grove, 2005:548). Data analysis was concluded when saturation was obtained.

\section{MEASURES FOR ENSURING TRUST- WORTHINESS}

The trustworthiness of the study was ensured by attentiveness to the qualitative criteria of credibility, transferability and dependability.

Guba's model (Lincoln \& Guba, 1985:301) was also used to ensure trustworthiness in this research. Table 1 summarises the strategies to ensure trustworthiness.

\section{ETHICAL CONSIDERATIONS}

Participation in this study was voluntary and informed consent was obtained. In addition, measures were implemented to ensure anonymity and confidentiality. No names of students or training institutions were provided.

\section{DISCUSSION OF THE RESULTS}

The main themes that emerged from the data analysis are:

- Experiences include feelings of discomfort in observing nursing care being delivered.

- Experiences include feelings of cultural shock.

- Expressions of appreciation for clinical exposure.

Table 1: Strategies to ensure trustworthiness

\begin{tabular}{|c|c|c|}
\hline Strategy & Criteria & Applicability \\
\hline \multirow[t]{4}{*}{ Credibility } & $\begin{array}{l}\text { Prolonged } \\
\text { engagement }\end{array}$ & $\begin{array}{l}\text { Sufficient time was invested with international } \\
\text { students to build trust and understanding. }\end{array}$ \\
\hline & $\begin{array}{l}\text { Authority of researcher } \\
\text { (Robinson \& Gmeiner, } \\
\text { 1998:17) }\end{array}$ & $\begin{array}{l}\text { The researcher has had previous training in the } \\
\text { research methodology. The research was } \\
\text { supervised by a faculty member who has extensive } \\
\text { experience in conducting qualitative research and } \\
\text { also participated in a trans-cultural qualitative study. }\end{array}$ \\
\hline & Member checking & $\begin{array}{l}\text { The researcher did member checking with } \\
\text { participants to verify whether what they wrote was a } \\
\text { true reflection of their experience. }\end{array}$ \\
\hline & Field notes & $\begin{array}{l}\text { During informal meetings with students, the } \\
\text { researcher made field notes. }\end{array}$ \\
\hline \multirow[t]{2}{*}{ Transferability } & Thick descriptions & $\begin{array}{l}\text { A thick/dense description refers to a rich thorough } \\
\text { description of the research setting, transactions and } \\
\text { process observed during inquiry (Polit \& Beck, } \\
\text { 2006:336). Complete descriptions of design, } \\
\text { methodology and literature control to maintain } \\
\text { transparency. }\end{array}$ \\
\hline & Nominated sample & The sampling was purposeful. \\
\hline \multirow[t]{2}{*}{ Dependability } & Thick descriptions & The research methodology was clearly described. \\
\hline & Peer examinations & $\begin{array}{l}\text { Independent checking by a colleague with } \\
\text { experience in the field of qualitative research. }\end{array}$ \\
\hline
\end{tabular}


The following discussion on these three themes will attempt to give meaning to the experiences of student nurses visiting Namibia.

\section{Theme 1: Experiences include feelings of discomfort}

Discomfort entailed the following feelings:

- Discomfort experienced in observing nursing care being delivered.

- Discomfort in experiencing the plight of patients.

\section{Discomfort experienced in observing nursing care being delivered}

In this study the visiting nursing students described feelings of discomfort and even tension with regard to care delivery that was different to which they were culturally attuned.

They expressed their uneasiness about how aspects of pain control, hygiene and communication are dealt with in hospitals in Namibia. Of the comments were: "Patients have to manage more pain than that what we are used to at home" (sic); "The (Namibian nurses) do not use so much pain killers as we are used to" (sic). These observations accord with the field notes of the coordinator and with the comments she heard these students make.

This theme of discomfort in observing care delivery is echoed by the references to differences in hygienic practices: "I found out that there are many differences between our cultures. The way we treat people and hygiene"; "Our first impression was the lack of what was regarded as absolute necessary equipment, such as hot water...".

They describe their experiences as being different from what they are accustomed to; in particular, there is a big difference in how nurses care for the patients. As some students noted: "It is also hard to see that hygiene conditions are not always what it should be. Maybe the way we treat patients in (...) is far too luxurious" (sic); "Sometimes it seems to us that the knowledge about hygiene is low". In a study on hygienic practices in a specific region in Namibia, the authors also concluded that certain aspects of hygienic care as provided by nurses, needed improvement (Van Dyk, Small,
Van der Merwe \& Mueyu, 2004:85).

Communication issues were also noted as obstacles to effective caring. Students were quick to notice the lack of therapeutic communication. For example, they commented as follows: "Nurses do not pay attention to patients. In (...) we listen to the patients. They do not have a real conversation with them - take time. When we have time left, we try to listen to our clients" (sic).

In this regard, language, and more specifically the correct and sincere use of it, is known to be a facilitator in good nursing care delivery. In this regard Kozier, Erb, Berman and Snyder (2004:206) observe that culture and language are vital factors in how nursing care is delivered and received, and that there is the expectation that diverse cultural needs should be met (Kozier et al. 2004:206).

To render culturally competent care implies that a nurse attends to the total context of the patient's situation by using a complex combination of knowledge, attitudes and skills (Kozier et al. 2004:207). This means knowledge about your patient's language and the correct attitude towards a patient who has difficulty with the official language.

\section{Experience of discomfort in observing the plight of patients}

This pattern emerged as feelings of surprise and emotional discomfort. Students responded as follows: "We have experience some tough situations - like dying children with HIVIAIDS and TB. These are diseases that we are not used to in (...). Some of the mothers look a bit relieved when the baby is dying because of the diagnose and its pain." (sic); "Sometimes we've experienced things that are difficult to bear on your own... important for us to have an open-minded dialogue in the group"(sic); "We all experienced such emotional episodes for the first weeks".

This emotional uneasiness was often coupled with expressions of sympathy: "It was not easy for me sometimes, facing the health problems of those little children knowing how terrible the conditions at home can be"; "for (...) personally the encounter with HIV - positive children was tough.... She felt she had no possibility to prepare herself for this". 
In research done by Eliason and Raheim (2000:163), it was also identified that students exposed to diverse cultures had deep feelings of sympathy and pity for less fortunate patients.

\section{Theme 2: Experiences include feelings of culture shock}

Duffy (2001:493) considers culture shock to be the collision of two or more sets of values. This situation is even more aptly defined by Kozier et al.(2004:209), who describe culture shock as a "disorder that occurs in response to transition from one cultural setting to another".

In this study, this is exactly what occurred. Student nurses left first world countries, mainly Scandinavian countries, to embark on a nursing field visit to a mainly third world country, in this case Namibia. It could be expected that they would experience some sort of "cultural shock", as it is a well documented phenomenon. Specifically, it developed from exposure to unaccustomed differences in climate, food, money, accommodation, language and social etiquette (Button, Green, Tengnah, Johansson \& Baker, 2005:322).

This is not a comfortable experience, as shown by the students' narratives. For example, experiences of tension and feelings of being lost were described. Students put it as follows: "My first day at hospital was very interesting and a little bit scary"; "We are trained to think of the patient as the most important person ... deal with physical side but also with psychological side. This difference between the two countries have been discussed a lot amongst us"; "There have been difficult and demanding situations but we felt that we became 'stronger'"'.

What was evident from these quotations was that although these students did receive theoretical preparation on aspects of trans-cultural nursing, the practical or real side of it could be a bit of a "shock" or scary. It is interesting to note their mentioning the differences between the "two countries". The notion of "us" versus "them" in this quotation suggests that they use their own background or even their country as terms of references. In the process they also employ terminology like "scary", "demanding" and "becoming stronger".
In addition patterns of sensory overload were also discovered. As some students highlighted it: "its many new and strange smells"; "I felt like stepping into another world"; " "On our night, we have never seen as much blood as this our whole life (casualty)" (sic).

Again, this "another world" could be made more understandable with applicable guidelines. It could help them to put at least some experiences within a logical framework, as the next quotation demonstrates: "Surprisingly for us, there were no fathers at the maternity" (sic).

This quotation reflects lack of information about cultural customs in Namibia. Being mostly a third world country, many expectant mothers might have no option but to enter this stage in their life on their own, accompanied by other "significant others", who not necessarily include the fathers. Also, there is the prospect that some might be single mothers. Here it should be noted that this is a matter of custom and choice, because partners are always welcome to attend a birth. However, only amongst the more affluent population groups, do fathers regularly attend the birth of their children (Pretorius \& Small, 2006).

Some of the overtly negative experiences that were also narrated were not directly linked to nursing per se, but to the context within which the nursing service is delivered. This includes incidents of theft in their living quarters or of being robbed while on their way to the hospital. The quotation below encapsulates this aspect: "we also had sad and frightening experience".

The incident, to which the quotation refers, was not the only one. On more than one occasion, the coordinator was contacted to assist when a theft or robbery occurred. Although students are briefed on issues of safety when they embark on their visits to Namibia, it is likely that they are not provided with "specific information" such as the best times to travel, where to stay, and what type of transport to use, to name but a few examples, all of which could be included in appropriate guidelines.

\section{Theme 3: Expressions of appreciation for clinical exposure}

Many students concluded their comments on very positive notes, indicating their appreciation towards both 
their Nursing School and the host institution for granting them the opportunity to be part of a trans-cultural encounter. The coordinator (co-researcher) is of opinion that this is valuable information in support of the preparation programme for trans-cultural encounters to Namibia.

The following are some of the ways in which the students expressed their appreciation: "Thank you ... for having been there for us"; "It has given us wonderful experience to work here, both on professional and personal level, experiences we will carry with us for the rest of our lives. Thank you."; "We all agree that the benefit of the internship depends totally on personal initiative"; "We have seen that the health system here in Namibia is working"; "We have learned about different cultures ... and exotic sicknesses"; "I will remember this for the rest of my life".

A pattern of astonishment and surprise was also evident in some narratives as illustrated by the following: "In this ward (casualty) we have seen more in two weeks than in a year in a hospital in (...) and it has been a great experience"; "What an exciting experience (operating room/theatre)". To conclude this theme, the following statement by a student wraps it all up: "Looking back at my stay in Namibia I find that the things I experienced down there has had an impact on me that probably would make better as a nurse".

\section{SUMMARY OF RESULTS}

Three main themes emerged form these narratives:

- $\quad$ experiences included recognition of differences in care delivery;

- $\quad$ experiences included feelings of culture shock; and

- expressions of appreciation for clinical exposure.

It was noted that some of these themes contain negative emotions and possibly negative "belief systems" which means that visiting nursing students may leave Namibia with the belief that some of the "wrong" they saw are culturally acceptable in Namibia.

It is thus important to provide these students with the correct information, which would help them to evaluate situations so that they would understand that certain behaviours are not necessarily accepted or culturally condoned. Thus, the following information guidelines were developed to be submitted to the Ministry of Health and Social Services, as well as to the Department of Nursing at the University of Namibia. As they are only guidelines, they can be expanded and adapted, should the need arise.

\section{INFORMATION GUIDELINES}

It is recommended that both the University of Namibia (Department of Nursing), and the Ministry of Health and Social Services, consider the inclusion of the following guidelines in an information booklet as outlined in Table 2

\section{LIMITATIONS OF THE STUDY}

Because of difficulties in expressing themselves in English, many of the visiting student nurses had difficulty in expressing their experiences precisely.

\section{CONCLUSIONS}

It has been claimed that nurses have a moral obligation to provide quality care, which includes culturally appropriate care; thus, educational institutions have a social responsibility to prepare their students for multicultural care (Button et al. 2005:315).

For quality care, it is an academic principle that people should be well prepared when entering the clinical field for practice. This is even truer when the clinical field is in another country. To be well prepared, information must be provided in advance. If this is not the case, cultural experiences might be imperfectly understood, or sometimes misinterpreted.

Literature shows that international placements are beneficial to the professional progress of nursing students. In addition, both unpleasant and positive experiences are valuable, in that students must learn to accept differences in health care practice. Learning as much as possible about a culture before immersing oneself in it, also strengthens a course (Button et al. 2005:318; Pickrell, 2001:128).

Caroline Polt, a nurse who went to Saudi Arabia for practical experience, stated that an orientation 
Table 2: Guidelines for inclusion in an information booklet

\begin{tabular}{|c|c|}
\hline Topics for inclusion & Comments \& rationale \\
\hline $\begin{array}{l}\text { 1. Guidelines to assist familiarisation } \\
\text { with Namibia } \\
\text { • } \quad \text { The size of the country } \\
\text { - } \quad \text { Its population profile } \\
\text { - Its ethnic history } \\
\text { - Its language policy }\end{array}$ & $\begin{array}{l}\text { - To assist in gaining an understanding about } \\
\text { the vast size of the country and the difficulty } \\
\text { in delivery a health care service in such a } \\
\text { situation. } \\
\text { - To assist in gaining an understanding of } \\
\text { relevant health demographics as well socio- } \\
\text { economic aspects. } \\
\text { - To assist in gaining an understanding of } \\
\text { relevant ethno-histories as well as its impact } \\
\text { on health and health care delivery. } \\
\text { - To assist in gaining an understanding that } \\
\text { although the official language is English, the } \\
\text { lingua franca might be different and might } \\
\text { have an impact on health care delivery. } \\
\text { - To assist them in identifying persons to } \\
\text { help them with translations should the need } \\
\text { arise. } \\
\text { - To encourage them to work in groups in } \\
\text { order to clarify communication problems and } \\
\text { also to clear uncertainties with the } \\
\text { coordinator. }\end{array}$ \\
\hline $\begin{array}{l}\begin{array}{l}\text { Guidelines to assist understanding of } \\
\text { the health infra-structure }\end{array} \\
\text { - Role of the Ministry of Health and Social } \\
\text { Services } \\
\text { - } \quad \text { Role of the private sector } \\
\text { Role of traditional health workers }\end{array}$ & $\begin{array}{l}\text { - To assist in gaining an understanding of the } \\
\text { relationships amongst care providers. } \\
\text { - To sensitise them about to subtle } \\
\text { differences between private and state } \\
\text { patients (first world versus third world). } \\
\text { - To explain the continuing impact of } \\
\text { traditional health workers. } \\
\text { - To sensitise the students to safety issues } \\
\text { when visiting and leaving the state hospital } \\
\text { facilities. }\end{array}$ \\
\hline $\begin{array}{l}\text { Health belief systems in Namibia } \\
\text { - Western belief systems } \\
\text { - Traditional belief systems }\end{array}$ & $\begin{array}{l}\text { - To assist in gaining an understanding of the } \\
\text { existence of a dual health belief system in } \\
\text { Namibia. } \\
\text { - To sensitise the visiting nursing students } \\
\text { about different hygienic practice (culturally } \\
\text { related). } \\
\text { - To sensitise the visiting nursing students } \\
\text { about traditional ways of communication. } \\
\text { - To highlight the acceptance/non- } \\
\text { acceptance of the fathers' presence during } \\
\text { delivery. }\end{array}$ \\
\hline
\end{tabular}




\begin{tabular}{|l|l|}
\hline - $\begin{array}{l}\text { Nursing care philosophy in Namibia } \\
\text { - }\end{array}$ & $\begin{array}{l}\text { - To assist in gaining an understanding that } \\
\text { an ethics of caring is regarded as universal. } \\
\text { Deviations are regarded as shortcomings } \\
\text { and not a "rule" of nursing in Namibia. } \\
- \text { To assist in gaining an understanding that } \\
\text { unnecessary pain experiences by patients' } \\
\text { are not condoned. }\end{array}$ \\
\hline - Negal aspects of nursing care in & $\begin{array}{l}\text { - To assist in gaining an appreciation of the } \\
\text { fact that the type of nursing interventions } \\
\text { observed may be different from those that } \\
\text { the visitor expects. } \\
\text { - So assist in gaining an understanding of the } \\
\text { - Scope of practice }\end{array}$ \\
- Accountability and responsibility & $\begin{array}{l}\text { Independency/dependency } \\
\text { to act "more independently". } \\
\text { - To inform the visiting nursing students } \\
\text { about risk management issues. }\end{array}$ \\
\hline
\end{tabular}

programme is necessary to provide incoming staff with an introduction to the local culture (Polt, 2005:1). Kozier and others (Kozier et al. 2004:218) state that nurses who wish to render care to people of different cultures need to be aware of any health beliefs and practices that are different from their own (western) style.

All of these observations are borne out by our own experiences and research, which show both the difficulties that are inherent in trans-cultural experiences and the possibilities of reconciling these differences in productive and meaningful ways.

\section{REFERENCES}

ANDREWS, MM \& BOYLE, N 1999: Transcultural concepts in nursing care; $3^{\text {rd }}$ edition. Philadelphia: Lippincott.

BURNS, N \& GROVE, SK 2005: The practice of nursing research. Conduct, critique \& utilization. Philadelphia: WB Saunders Company.

BUTTON, L; GREEN, B; TENGNAH, C; JOHANSSON, I \& BAKER, C 2005: The impact of international placements on nurses' personal and professional lives: Literature review. Journal of Advanced Nursing, 50(3):315-324.

DUFFY, M 2001: A critique of cultural education in nursing. Journal of Advanced Nursing, 36(4):487-495.

ELIASON, MJ \& RAHEIM, S 2000: Experiences and comfort with culturally diverse groups in undergraduate pre-nursing students.
Journal of Nursing Education, 39(4):163.

KOZIER, B; ERB, G; BERMAN, A \& SNYDER, S 2004: Fundamentals of nursing concepts, process and practice; International edition. New York: Pearson Educational International.

LEININGER, M \& McFARLAND MR 2002: Transcultural Nursing. Concepts, theories, research \& practice; $3^{\text {rd }}$ edition. New York: McGraw Hill.

LINCOLN, YS \& GUBA, EG 1985: Naturalistic theory. Beverley Hills: SAGE.

PICKRELL, KD 2001: A crosscultural nursing experience on the Rosebud reservation. Nurse Educator, 26(3):128.

POLIT , DF \& BECK, CT 2006: Essentials of nursing research: Methods, appraisal and utilization; $6^{\text {th }}$ edition. Philadelphia: Lippincott-Raven.

POLT, CA 2005: Beyond my expectations. A crosscultural journey in the desert kingdom. http://www.medhunters.com/articles/ beyondMyExpectations.html. (Accessed: 11 August 2005). PRETORIUS, L 1995: Report on international nursing students. Windhoek: University of Namibia.

PRETORIUS, L \& SMALL L 2006: February 12. Observation by authors: $L$ Pretorius and L Small, University of Namibia. Windhoek. ROBINSON, I \& GMEINER, A 1998: Policemen's perception of their experience working in a high risk area. Health SA Gesondheid, 3(3):17-23.

VAN DYK, A; SMALL, LF; VAN DER MERWE, T \& MUEYU, M 2004: The quality of nursing care regarding personal hygiene of patients admitted to a selected hospital in the Kavango region. Curationis, 27(3):85-92. 